Ondokuz Mayıs Üniversitesi İnsan Bilimleri Dergisi,

Ondokuz Mayıs University Journal of Humanities

e-ISSN: 2717-8072, IBD, December 2021, 2(2): 81-96

\title{
Kuruluşundan 19 Mayıs 1919’a Samsun
}

\section{Samsun, from its Foundation to 19 May 1919}

\author{
Prof. Dr. Nedim İPEK \\ 1 Ondokuz Mayıs Üniversitesi Fen-Edebiyat Fakültesi \\ • nedimipek@hotmail.com• ORCID > 0000-0001-9239-1333
}

\author{
Makale Bilgisi / Article Information \\ Makale Türü / Article Types: Araştırma Makalesi / Research Article \\ Geliş Tarihi / Received: 14 Ekim / October 2021 \\ Kabul Tarihi / Accepted: 3 Kasım / November 2021 \\ Yıl/Year: 2021 | Cilt-Volume: 2 | Sayı-Issue: 2 | Sayfa/Pages: 81-96
}

Atıf/Cite as: Ipek, N., "Kuruluşundan 19 Mayıs 1919'a Samsun - Samsun, from its Foundation to May 19 1919”, Ondokuz Mayıs Üniversitesi Insan Bilimleri Dergisi - Ondokuz Mayıs University Journal of Humanities, 2 (2), Aralık 2021: 81-96.

https://10.51533/insanbilimleri.1014399 


\section{KURULUŞUNDAN 19 MAYIS 1919'A SAMSUN \\ SAMSUN, FROM ITS FOUNDATION TO 19 MAY 1919}

ÖZ:

Samsun Selçuklular tarafından kurulan bir kalekenttir. 19. yüzyllin ortalarına kadar Türk nüfusun yaşadığı bir kasaba hüviyetindedir. Ticaretin serbestleşmesi ile birlikte 1850 sonrası nüfus ve saha açısından hızla büyüyecektir. Ayrıca, yangını müteakip 1870 sonrası planlı bir şehir görünümü kazanacaktır. Bu büyümeye paralel şehrin nüfus yapısı bir hayli değişecektir. Özellikle, iç göç sonucunda müslüman nüfus kadar gayrimüslim nüfusun da ikamet ettiği bir yerleşme halini alacaktır. $1890^{\prime} l 1$ ylllardan itibaren Ermeni ve Rumlar siyasi amaçlı örgütlenmiştir ve çeteler kurarak bölgenin asayişini bozucu hareketlere başlamışlardır.

Böyle bir ortamda Mustafa Kemal Paşa 19 Mayıs 1919 günü Samsun'a çıkar. Tarihi olayların anlaşılması ve algılanmasında mekânın önemi tartışlmazdır. Bu makalenin amacı kuruluşundan 1919 yılına kadar gelişim ve değișimi ana hatları ile değerlendirmek ve Millî Mücadele'nin başlatıldığı Samsun'un 19 Mayıs 1919 günü içinde bulunduğu sosyal, iktisadi ve demografik yapısını ortaya koymaktadır.

Anahtar Kelimeler: Samsun, Millî Mücadele, Rum, Ermeni.

\section{ABSTRACT:}

Samsun is a Seljuk-founded fortress city. It was a town populated by Turks until the mid-nineteenth century. After 1850, when commerce was liberalised, it grew rapidly in terms of population and land. Additionally, following the fire, it took on the aspect of a planned metropolis in the years following 1870 . Parallel to this development, the city's demographic structure underwent significant changes. In particular, as a result of internal migration, it became a settlement that was home to both non-Muslims and Muslims. Since the 1890s, Armenians and Greeks organised for political reasons and began disrupting regional security through the formation of gangs.

Mustafa Kemal Pasha arrived in Samsun on 19 May 1919 in this circumstances. It is undeniable that placement plays an important role in comprehending and perceiving historical events. The purpose of this article is to evaluate Samsun's development and change from its founding until 1919, as well as to show the social, economic and demographic structure of Samsun, where the National Struggle began on May 19, 1919.

Keywords: Samsun, National Struggle, Greek, Armenian. 
Bugünkü Samsun vilayeti toprakları paleolitik çağdan beri iskan sahası olmuştur. Doğu Karadeniz bölgesine yerleşen gruplar içerisinde ismi bilinen en eski topluluk Gaşkalardır. Ardından Kafkasya üzerinden Anadolu’yu istila eden Kimmerler gelmektedir. Kimmer boyları, Ereğliden Trabzon'a kadar olan sahayı ellerine geçirmişlerdir. Kimmerler muhtemelen şiddetini arttıran İskit baskısı sonucu bölgeyi terk ederek Karadeniz’in kuzey sahillerine geçtiler. Samsun'a yerleşen Asyalı ikinci topluluk İskitler (Sakalar) idi. Hunların sıkıştırması ile Türkistan’ı terk eden İskit toplulukları Kafkasya, Anadolu ve Karadeniz havzasına doğru göç etmişlerdir. İskit topluluklarının ulaştığ yerler arasında Samsun da vardı. Boyabat üzerinden Karadeniz’e ulaşan İskitlerin hakimiyet alanlarını buradan Trabzon'a kadar bat1-doğu ve kuzey-güney istikametinde genişlettikleri ve buralarda İyon, Milet ve Yunanlı tacirlere koloni kurma imtiyazı tanıdıkları bilinmektedir.

Amisos isimli ticari koloninin Miletli tacirler tarafından M.Ö. 7. yüzyılın ikinci yarısında kurulduğu tahmin edilmektedir. Bu koloniden Foçalı ve İyonyalı tacirler de istifade etmişlerdir. Yunanlı tacirlerin ise bölgeye M.Ö. 5. yüzyılın ortalarında geldiği tahmin edilmektedir. Amisos ticarî kolonisi özellikle İpekyolu üzerinden Çin'den gelen emtianın batıya pazarlandığı bir yerdi. Ayrıca kolonide maden ve köle ticareti de bir hayli önemliydi. Bölgenin hâkimiyeti bundan sonra sırasıly Pontus Krallığı ve Roma İmparatorluğu’na geçti. Netice itibarıyla tarım ve hayvancılıkla uğraşan topluluklar Canik dağlarının kuzey eteklerinde ve özellikle güneyinde varlıklarını sürdürürken ticaretle uğraşan Batı Anadolu ve Yunanlı tacirler Amisos'a yerleşmiş durumdayd. Tarım ve hayvancılıkla geçimini temin eden topluluklar ile tüccar koloniciler arasında kültürel fark hatta mücadele vardı. Pontus krallığının merkezi Amisos kenti Roma- Pontus mücadelelerinden olumsuz etkilenmiş ve kentin erkek nüfusu M.Ö. 48'de Roma ordusu tarafından kılıçtan geçirilmiştir.

Roma hâkimiyeti döneminde Amisos, Hristiyanlığın bölgede yayıldığı ilk şehir oldu. Hristiyanlık kent halkını birleştiren bir güç konumuna geldi. 6. yüzyılda Doğu Roma İmparatorluğu, bölge halkının devlete bağlılığını arttırmak için Hristiyanlığı resmi din, Grekçeyi de ibadet dili haline getirdi. Bu karar sonrasında bölgede önemli değişiklikler yaşandı. Netice itibarıyla Gaşka, İskit, Kimmer, Yunan, Milet, Efes, İyon gibi farklı isimlerle anılan bölge halkı Roma / Rum adı altında birleşti ve kaynaştı.

11. yüzyıldan itibaren Çağrı Bey'in düzenlediği Batı seferiyle birlikte Selçukluların Karadeniz havzasıyla ilgi ve irtibatları başlamıştır. İbrahim Yınal liderliğindeki Türk kuvvetlerinin seferleri (1048) akın sahasındaki nüfus yapısında değişmeleri ve Bizans sınırları dâhilinde iç göçlerin hızlanmasını tetikledi. İç göçün yaşandığ 1 sahalardan birisi de Karadeniz bölgesidir. Malazgirt öncesinde Doğu Karadeniz’e yönelik Türk akınları sonucu Ermeni ve Gürcü Krallıkları ile Bizans 
İmparatorluğu’nun askerî gücü tükenme aşamasına getirildi. Tuğrul Bey’in 1054 seferi esnasında Çoruh Vadisi ve Canik ormanlarına kadar olan sahadaki Bizans kuvvetlerini ortadan kaldıran Türkmenler 1067/1068 akınında Trabzon’a kadar ilerlediler. Malazgirt sonrası Türkmen fetihleri bölgedeki Rum nüfusunu olumsuz etkiledi. Bütün kıyı bölgesi ve Yeşilırmak, Kızılırmak deltalarındaki Hıristiyan nüfus kısmen yerlerinden ayrıldı. Bizans idaresi bu nüfusu hakimiyetindeki diğer yerleşmelere sevk ve iskan etti.

Türkler bir taraftan Bizans idaresinin tahliye ettiği köy ve şehirlere yerleşirken, diğer taraftan iskana müsait gördükleri yerleri yurt tutmaya ve şenlendirmeye başlamışlardı. Türkmenler yer seçiminde hayvan sürülerini doyurabilecekleri geniş otlakları tercih etmekteydiler. Ayrıca yerleşecekleri yerin rutubetsiz kuru bir iklime sahip olmasını da arzuluyorlardı. Lâdik, Havza, Kavak ve Vezirköprü bu özellikleri taşıyan bir bölgeydi. Amisos’un içinde bulunduğu dar kıyı şeridi ise bu özelliklere sahip olmadığından Türklerin tercih ettiği bir iskân sahası değildi.

Doğu Karadeniz’in nüfus yapısının değişmesinde dönüm noktası Çağrı Bey'in Doğu Anadolu seferidir (1018). Büyük Türk kütleleri 1071'den itibaren Doğu Karadeniz’e iyice nüfuz etmeye başlayacak, doğuda Bayburt üstünden Trabzon- Rize; batıda Havza- Samsun üstünden sahil boyunca her iki yöne doğru genişleme harekâtı gerçekleştirecektir. Bu zemini Kızılırmak, Yeşilırmak ve Kelkit havzasını kontrol eden Danişmentliler oluşturacak, Saltuklu ve Mengücekler geliştirecektir. 1243 Kösedağ Savaşı sonrası Karadeniz'de Türk yayılması durmuştur. Bundan sonra Selçukluların görevini Canik beylikleri üstlenmiştir. Bu arada çeşitli Türkmen grupları yöreye sızmak suretiyle bölgedeki Türk varlğ̆ını sürekli besler. Moğolların önünden çekilen Türk gruplarının başında Çepniler gelir. Anadolu’nun Moğol idaresi döneminde de bölgeye Türk nüfus akışı devam etmiştir. Öte yandan aynı dönemde Kıpçaklar Batum- Rize arasına yayılır ve yerleşir.

Canik sahasının Türkleşmesinde beylikler oldukça etkili olmuştur. Özellikle Niksar merkezli Danişmentliler Ünye, Bafra ve Çarşamba taraflarına Türk nüfus iskân etmiştir. Selçuklular 1178'de Amisos'un bir ok atımı doğusunda sahile ulaştılar. Amisos ele geçirilemeyince Rükneddin Süleyman Şah döneminde bugünkü Saathane mevkiinde bir kale inşa edildi. Bu kale Samsun kentinin temelini oluşturdu. 1178-1228 yılları arasında Sinop-Ünye sahil şeridi Türk hâkimiyetine girdi. Bölgedeki Türk nüfusu Kösedağ Savaşı sonrası artmıştır. Moğol baskısı Doğu, Orta ve Güney Anadolu'da yaşayan Türkmenlerin geniş yer değiştirmelerine sebebiyet verdi. Sinop-Samsun hattındaki Türk nüfusun artmasında özellikle Çepni göçü etkili olmuştur. 13. yüzyılda Doğu Karadenizde yayılmaya başlayan Çepniler 14. yüzyılda Harşit deresine ulaşmışlardır. 1341 yılında bağımsız bir konuma gelen Eretnalılar 1352 yilına kadar Ankara ile Erzurum arasında bulunan Amasya, Tokat, Samsun, Çorum, Sivas, Kayseri, Erzincan ve Bayburt şehirlerine 
hâkim oldular. Eratna hâkimiyeti döneminde Canik sahasındaki Türk toplulukları kendi başlarına hareket edebilmekteydi. Öte yandan Moğol istilasını müteakip Vezirköprü, Havza, Merzifon yöresine gelen Taşanoğulları söz konusu bölgenin Türkleşmesinde etkili olmuştur. ${ }^{[1]}$ Netice itibarıyla Canik daha Osmanlı hâkimiyetine girmeden önce Türk nüfus deposu halini almıştı. Canik sahası Çelebi Mehmet zamanında Osmanlı hakimiyetine dahil edilmiştir.

Samsun şehrin nüfusu kale mülazımları hariç 1485 'de 1.555 'i Türk ve 855 'i gayrimüslim olmak üzere toplam 2.410 kişidir. 1485 - 1520 yılları arasında Türk nüfus artarak 1.785 'e çıkarken, gayrimüslim nüfus 280'e kadar gerilemiştir. 15201576 sürecinde ise şehrin nüfusu azalmıştır. 1576 verilerine göre Türk nüfusu 1.400'e, gayrimüslim nüfus 165 'e gerilemiştir. Askeriler de hesaba katılırsa şehrin nüfusu 1.800’e kadar çıktığı söylenebilir. Celali hadiseleri ve Kozak saldırıları neticesinde şehrin nüfusu 17. Yüzyılın ikinci yarısına kadar azalmaya devam edecektir. Gayrimüslim nüfusun bu süreçte Kadıköy’e çekildiği tahmin edilmektedir. ${ }^{[2]}$ Şehirde oturanlar kısmen hububat yetiştirmekte ve bağcılıkla uğraşmaktaydılar. Evliya Çelebi'ye göre ise halkın tamamı gemici ve kendirci idi. 18. yüzyılın ikinci yarısında Samsun'da ayanlık güçlendi. Canikli ve Hazinedarzadeler yaklaşık 19. yüzyılın ikinci yarısına kadar bölgeye hâkim oldular. ${ }^{[3]}$

1834- 1845 yılları arasında gerçekleştirilen nüfus sayımlarına göre şehrin nüfusu 2.066 ile 2.178 kişi arasında değişmekteydi. Şehirde gayrimüslim nüfus ikamet etmiyordu. Sadece diğer şehirlerden gelen 160 gayrimüslim tüccar vard. ${ }^{[4]}$ 1838 Balta Limanı Sözleşmesi ile ticaretin serbestleşmesi sonucu Samsun nüfus ve ekonomik açıdan hızla büyüyecektir.

1860’lı yıllarda hummalı bayındırlık faaliyetleri sonucunda ortaya çıkan şehri 1869 yangını silip götürdü. Yangın sonrası şehir yeniden imar edilmeye çalışıldı. 1883 yılında şehrin doğusunda deniz kenarında yeni bir hükümet konağı, bir ahır ve bir de hapishane inşa edildi. İleri tarihlerde zabitan daireleri, kışla binası ve redif deposu inşa edildi. Ardından 1869 'da yanan caminin yerine hem dini ihtiyacı karşılamak ve hem de şehri sembolize etmek adına Hamidiye (Valide Sultan ) camii inşa edildi. Belirtmek gerekirse bu caminin yanı sıra şehirde 10 cami, 3 mescit, 4 tekke ve 4 kilise mevcuttu.

1 Osmanlı öncesi Canik ve mücavir alandaki gelişmeler için bk. İbrahim Tellioğlu, "Osmanlı Hakimiyetine Kadar Canik", Ilkçağdan Cumhuriyete Canik, Samsun 2012, s. 23-67; Ibrahim Tellioğlu, Ilkçağdan Osmanlılara Samsun, Samsun 2012.

2 15. ve 16. yüzyıllarda şehrin nüfusu gelişimi ve değişimi için bk. Mehmet Öz, XV-XVI. Yüzyıllarda Canik Sancağı, Ankara 1999.

3 Ayanlık döneminde Canik için bk. Rıza Karagöz, "Canik'in İdari Yapısı ve İdarecileri”, ilkçağdan Cumhuriyete Canik, Samsun 2012, s. 119-162; Rıza Karagöz, Canikli Ali Paşa, Ankara 2003; Rıza Karagöz, Karadeniz'de Bir Hanedan Kurucusu Haznedarzade Süleyman Paşa, Samsun 2010.

4 1834-1845 yılları arasında yapılan nüfus sayım sonuçlarının değerlendirilmesi için bk. Nedim İpek, vd, Canik Sancağı Samsun Kazasının Nüfus Yapısı (1834-1845), Samsun 2016. 
Yangın sonrası yerel idare ve halkın çabalarıyla şehrin modernizasyonu gerçekleştirilmeye çalışılırken göçler neticesi nüfusu artan şehir boş vadilere, şehrin güneyindeki sırtlara doğru büyümeye başladı. Sadibey mahallesinin Kadıköy caddesi tarafina göçmenler yerleştirildi. Yeni kurulan bu mahalleye Mecidiye adı verildi. Selahiye bölgesi 1870'li yıllarda zeytinlik, incirlik, boş tarla ve arsalardan ibaretti. Bazı yerleri koru manzarası arz ediyordu. Burada av partileri bile düzenlenebiliyordu. Bu semt civar şehir ve kasabalardan bilhassa Kayseri, Çorum, Merzifon, Tokat gibi yerlerden ticaret için gelip yerleşen Ermeni ve Müslüman ailelerle gittikçe büyümeye başladı. Şehirdeki işyeri sahipleri arasında yerli olanlar oldukça azdı. Çoğu memuriyetle başka yerlere gidiyordu. Bunların boşalttığı yerlere Orta Anadolu'dan gelen Rumlar yerleşmekteydi. 1895'te Kışla ve Kırbaç mevkileri parsellenip iskâna açıldı. Buralarda Kırbaç, Reşadiye ve Kışla isimli mahalleler kuruldu. Rumlar bu yeni mahallelere taşındılar.

19. yüzyılda buharlı gemilerin Karadeniz'de trafiğe çıkması, tütün ziraatının başlaması ve Anadolu’ya yönelik göçler Samsun limanını Karadeniz’de ön plana çıkarttı. Bu gelişmeler üzerine Avrupalı tüccarlar da Samsun’a yerleşmeye başladılar. Başta hububat, tütün ve deri olmak üzere çeşitli hammaddelerin dışsatımı hızlandı. 1838 Sözleşmesi ile zirai ürün üzerindeki tekel kalkınca Canik bölgesi Avrupa pazarlarına açıldı. Kırım Savaşı bölge limanlarında patlamaya sebep oldu. Artan talebi Samsun karşılayamaz oldu. Nihayet 1880'li yıllarda deniz kara bağlantısını daha da kolaylaştırmak amacıyla belediye bir demir iskele inşa ettirdi. İleriki tarihlerde Şimendifer, Yolcu, Tütün, Gümrük, Gaz, Dakik, Zahire isimli iskeleler de inşa edilip hizmete alındı.

19. yüzyılın sonu itibarıyla Samsun - Sivas, Bafra - Samsun - Çarşamba - Terme - Ünye ve Kavak - Erbaa karayolları hizmete alındı. Böylece Samsun bir yandan Doğu Karadeniz’e, diğer yandan Doğu Anadolu ve Orta Anadolu'ya karayolları ile bağlanmış oluyordu. Orta Anadolu’nun Karadeniz limanlarına bağlanması sonucu İç Anadolu'dan gelen mallar Samsun limanından ihraç edilir oldu. İthal ürünler de aynı şekilde limandan karayolu vasıtalarıyla Orta Anadolu ve Doğu Anadolu’ya sevk ediliyordu. 1910 'da bu yol otomobil işleyecek bir hale getirilmeye çalışıldı. Aynı tarihlerde Samsun - Sivas demiryolu da projelendirilmiş hatta inşaat çalışmaları da başlatılmışt1. ${ }^{[5]}$

20. yüzyılın başlarında Samsun şehrinin güneyinde mürtefi bir alanda Mutasarrıf Hamdi Bey'in gayretleriyle inşa ettirilen iki katlı bina II. Abdülhamid'in 25. cülus yıldönümünde Hamidiye hastanesi adı ile hizmete alındı. Bunu 1913-1915 yılları arasında Necip Bey tarafından inşa ettirilen üç katlı belediye binası takip

5 Canik sancağındaki bayındırlık çalışmaları için bk. İbrahim Serbestoğlu, Tanzimat, Teftiş ve Canik Sancağında Modernleşme, Ankara 2019; Nedim İpek, "Samsun-Sivas Demiryolu”, CiEPO Osmanlı Öncesi ve Osmanlı Araştırmaları Uluslararası Komitesi 17. Sempozyumu Bildiriler, Trabzon 2006, s. 863-874. 
etti. ${ }^{[6]}$ Aynı dönemde iki önemli proje daha vardı. Birincisi şehrin su ihtiyacını karşılamaktı. Şehrin su ihtiyacı sarnıç ve kuyulardan temin edilme yoluna gidilmişti. Daha sonraları Mert Irmağı’nın yukarı kesimlerinden düzgün olmayan kanallarla getirilen su şehirdeki çeşmelere dağıtılmıştı. 20. yüzyılın başında 5 şadırvan ve 35 adet umuma mahsus çeşme vardı. Ancak mecut su kamu sağlığı açısından sağlık$l_{1}$ değildi. Bunun üzerine Mert Irmağı kenarında açılacak kuyulardan temin edilecek suyun evlere dağıtılması ile ilgili bir proje hazırlandı. Keza aynı proje kapsamında elektrik üretimi de söz konusuydu. Aynı dönemde limanı Orta Anadolu’ya ve Mezopotamya'ya bağlayacak olan demiryolu hattı inşaatına başlandı. Ancak üç proje de Osmanlı döneminde hayata geçirilemedi.

Söz konusu imar faaliyetleri sonucu Samsun modern bir kent kimliğine kavuştu. 1869 yangını öncesi Samsun 1.103 meskenin yer aldığı bir yerleşme idi. 20. yüzyılın başında mesken sayısı \% 128'lik bir artış göstererek 2.624'e çıkmıştır. Keza, han adı verilen kurumun tasfiye olduğu anlaşılmaktadır. Bunun yerine oda adı verilen müessese ortaya çıkmıştır. Aynı zamanda şehirde misafirhane ve otel mevcuttur. Keza lokanta kurumu ve kavramı Samsun’a girmiştir. Fırın sayısı iki misli artarak 70'e yükselmiştir. ${ }^{[7]}$ Dükkân sayısı biraz azalırken, mağaza sayısı \% 338'lik bir artış göstermiştir. Bu da şehirlerarası ve uluslar arası ticaretin çok yoğunlaştığının bir göstergesi olsa gerektir. Şehirde konaklayan asker ve sivil yolcu sayısı her geçen gün artmaktaydı. Yolcular yeter miktarda sefere tahsis edilmiş geminin olmaması sebebiyle zorunlu olarak konaklama süresini uzatıyorlardı. Özellikle asker sevklerinin gerçekleştiği günlerde barınma ihtiyacı karşılanamıyordu. Bu gibi hallerde sahillerde çadırlardan oluşan kamplar kuruluyordu. Sivil yolcuların ise han ve otel gibi müesseselerde barındırılması gerekiyordu. 1890'l yıllar itibarıyla Samsun iskelesine gelen ve giden yolcu sayısı toplam 33 bini buluyordu. Şehirde mevcut olan otellerin yatak kapasitesi talebi karşılayacak sayıda değildi. Öte yandan sağlığa uygunluk ve kalite açısından da iyi hizmet sunamıyorlardı. ${ }^{[8]}$ 19. Yüzyılın sonu itibarıyla diş ve iç göçler neticesi şehrin nüfusu birkaç misli arttı̆̆ 1 gibi müslim ve gayrimüslim nüfus da hemen hemen eşitlenecektir. 1911 yılı itibarılyla şehrin nüfusu 6.443'ü erkek, 6.355'i kadın olmak üzere toplam 12.798 kişidir. ${ }^{[9]}$ Bunun \% 47.2'si gayrimüslimdir. Şehrin 1918'de nüfusu 25.104 kişidir. ${ }^{[10]}$

Birinci Dünya Savaşı esnasında Rus donanmasına ait savaş gemileri tarafından 10 Temmuz 1915'de şehir bombalandı. Bombardıman sonrası rüsumat dairesine

6 Nedim Ipek, "Kuruluşundan Cumhuriyete Canik Sancak Merkezi Samsun Şehri", Ilkçağdan Cumhuriyete Canik, Samsun 2012.

7 Mihail Vasilyeviç Frunze, Frunze'nin Türkiye Anıları, Çeviren. Ahmet Ekeş, İstanbul 1996, s. 29-37.

8 Nedim İpek, "Kuruluşundan Cumhuriyete Canik Sancak Merkezi Samsun Şehri", ilkçağdan Cumhuriyete Canik, s. 208.

9 BOA, Dh. Mui. Nu. $145 / 18$.

10 Halit Eken, "Mutasarrıf Hamid Bey'in Özel Notlarında 1919 Yilında Canik Sancağındaki Siyasi Olmayan Asayiş Sorunları ve Çözüm Arayışları", 19 Mayıs ve Milli Mücadelede Samsun Sempozyumu, Samsun 2000, S. 123. 
ait binaların yanı sıra Reji idaresine ait şimendüfer iskelesi ve gazhane deposu, sivil halka ait meskenler ile iskelenin açıklarında demirlemiş irili ufaklı 16 gemi tahrip oldu. 1916 ve 1917 yıllarında da Samsun sahilleri topa tutuldu. ${ }^{[11]}$

1919 yılında 15. Fırka Samsun’a konuşlandı. Fırkanın şehirdeki garnizonunda 121'i rütbeli olmak üzere toplam 2.652 asker bulunmaktayd ${ }^{\left[{ }^{[12]}\right.}$ Kasabadaki sivil halk çiftçilik, tüccarlık, balıkçılık, kayıkçılık, sarraflık, komisyonculuk, tütüncülük, hamallık, demircilik, taşçlık, dülgerlik, bakırcılık, marangozluk, kuyumculuk ve bahçıvanlık gibi zanaat ve işlerle geçimlerini temin etmekteydiler. Şehirde yevmiyeci ve işçi statüsünde çalışan kişiler de vardı. En fazla işçi istihdam eden kurum Reji idaresine ait tütün fabrikasıydı. Şehirde işçi istihdam eden tütün şirketleri de mevcuttu. Bunlar yerli ve yabancı sermayedarlardan oluşmuştu. En ünlüsü iki Amerikan şirketidir. Bunların istihdam ettiği teknik bürokrat ve işçilerin hemen tamamı Rum'du. Geçimini esnaflık, ticaret ve amelelikle temin edenler üç guruba ayrılabilir: Birinci gurubu herhangi bir mesleği olmayıp hamaliye gibi günübirliğine ağır ve kaba işlerde çalışanlar oluşturmaktaydı. Bunlar genellikle bekâr olup pek azının evi vardı. Evi olmayanlar gündüzleri sokaklarda ve kahvehanelerde, bir dükkân veya fırının kapısında sabahlıyorlardı. Hamalların çoğu Kırım ve Kafkas göçmeniydi. İkinci grubu taşçı, nalbant, fırınc1, boyac1, debbağ ve kayıkçı gibi yerleşik meslek erbabı oluşturmaktaydı. Bunlar şehrin orta tabakasıydı. Kentin modern bir limana sahip bulunmaması kayıkçı esnafının kalabalık olmasına sebebiyet vermekteydi. Açıkta demirleyen gemilerin yolcu ve yükleri mavnalarla taşınıyordu. Samsun limanında yükleme ve boşaltma işlerinde kullanılan mavna sayısı tahminen 92 adetti. ${ }^{[13]}$ Bunların en azından 65 tanesi sürekli kullanılabilir durumdaydı. Terzi, ayakkabıcı, çubukçu, dokumacı, şekerci, mobilyacı, kuyumcu ise şehrin en üst tabakasını oluşturmaktaydı. Kasaba sakinlerinin bir kısmı da bağcılık, çiftçilik ve zeytincilik ile meşgul olmaktaydı. Zira şehrin etrafındaki küçük tepeler zeytin ve incir ağaçlarıyla kaplıydı. Ancak Birinci Dünya Savaşı'nda bunlar resmî makamların ilgisizliği ve lakayt tavrı sonucu kurumuş veya kesilmişti. Yerlilerden esaslı bir iş tutan hemen az denilecek kadardı. Yerli halk daha çok memuriyete heves ederdi. Memur olmayı başaranlar şehri terk edip görev mahalline giderdi. Bu şekilde Samsun'u terk edenlerin bir kısmı çalıştıkları yere daimi olarak yerleşir, bir kısmı da tekaüt olduktan sonra geri dönerdi. Netice itibarıla memuriyete intisap etmek yerli halkın azalmasına sebebiyet veriyordu. Bunlardan boşalan yerleri Rumlar ve Ermeniler dolduruyordu. Ermeniler Hançerli mahallesinin üst tarafına doğru yerleşirken Rumlar ilk etapta Müslüman mahallelerinde mekân tuttular. Zamanla yeni inşa edilen Kırbaç, Reşadiye ve Kışla mahallelerine taşındılar. ${ }^{[14]}$

11 Osman Köse, “Rusların Samsun’u Bombardımanı (1915)”, Geçmişten Geleceğe Samsun, 2, Samsun 2007, s. 95-112.

12 Kocaoğlu, s. 18.

13 Anabasisten Atatürk'e Seyahatnamelerde Trabzon, Yay. Haz. Veysel Usta, Trabzon 1999, s. 155.

14 Samsun şehrinin kuruluş ve gelişimi için bk. Nedim Ipek, "Kuruluşundan Cumhuriyete Canik Sancak Merkezi Samsun Şehri”, ilkçağdan Cumhuriyete Canik, s. 164-226. 
Nüfusun bir kısmı da eğitim çağındaki çocuklardan oluşmaktaydı. Tanzimat'la birlikte söz konusu eğitim kuruluşlarına alternatif olarak Samsun'da iptidai, rüştiye, idadi ve darülmuallim gibi okullar açılarak eğitim - öğretime başladı. Tanzimat döneminde açılan mekteplerin temel amacı topluma Osmanlı kimliği kazandırmaktı. Söz konusu mekteplerden rüştiyenin öğrenci sayısı hızla artınca modern bir binaya ihtiyaç duyulur. Bunun üzerine 1890 'da kasabanın havadar bir mahalline yardımseverlerin katkısıyla bir rüştiye binasının inşasına başlanır ve kısa sürede bitirilerek hizmete alınır. 1898 itibarıyla Samsun Kız Rüştiyesi 79 öğrenciyle eğitim öğretim hizmeti vermekteydi. Aynı yıllarda Canik İdadisi açılır. Söz konusu okulun öğrenci sayısı yaklaşık 150 kişidir. II. Abdülhamid döneminin sonları itibarıyla şehirde üç medrese, bir rüştiye, bir idadi, üç iptidai ve birer tane de kız ve erkek hafız mektebi vardı. Ayrıca Ermeni ve Rum çocuklarının eğitim gördüğü birer mektep mevcuttu. Bu eğitim kuruluşlarının faaliyetlerinin sonucunda 20. Yüzyılın başlarında erkeklerin \%14'ü, kadınların \%6"sı eğitimlidir. Meşrutiyet döneminde temel eğitim amaçlı okul sayısı ve dolayısıyla öğrenci sayısı artmıştır. Bu okulların muallim ihtiyacını karşılamak amacıyla Fransızlara ait iken el konulan binada 1914 - 1915 eğitim - öğretim yılında 40-45 öğrenciyle Darülmuallim eğitim - öğretime başladı. Okul 1916'da hususi idare tarafından tamir edilen sultani binasına taşındı. Ancak aynı yıl yeterli öğrencisi olmaması sebebiyle kapatıldı. ${ }^{[15]}$

Samsun Kırım, Kafkaslar, Rumeli ve Anadolu'nun sair yerleşmelerinden nüfus göçü almıştır. Gelenler şehirde veya mücavir sahadaki köylerde mekân tuttular. Çoğunluğu çiftliklerde ve kamu hizmetinde istihdam edilmişti. Ticaret ve esnaflık icra edenler de vardı. Bir kısmı da hemşerilerinin iş yerlerinde amele olarak istihdam edilmekteydi. Hizmetçi olarak konaklara girenler de olmuştu. Aynı dönemde Samsun'dan diğer yerlere hatta Kafkaslara gidenler bile oluyordu. Ayrıca şehirde bini aşkın İranlı mevcuttu. ${ }^{[16]}$ Birinci Dünya Savaşı esnasında Rusların işgaline maruz kalan Trabzon vilayeti topraklarından kopan Müslüman mülteciler deniz veya karayolu ile Samsun'a sığındılar. Şehirde bulunan mülteci sayısı 18 bini aşmıştı. Mülteciler ilk etapta kamu binalarında ve metruk meskenlerde ikamet ettirilmeye çalışıldı. Belediye bunları imkânları ölçüsünde iaşe etmekteydi. Bununla beraber 1918 ve 1919 yıllarında Samsun'un sokak ve caddelerinde birçok yetim ve kimsesiz çocuk dolaşıyordu. İşte bu sıralarda Samsun'da bir darüleytam kuruldu ve çocukları himayesine aldı. Mütareke döneminde Kafkaslardan getirtilen 30 bini aşkın Rum sancak sınırları içerisinde yerleştirildi. ${ }^{[17]}$

15 Nedim Ipek, "Kuruluşundan Cumhuriyete Canik Sancak Merkezi Samsun Şehri", ilkçağdan Cumhuriyete Canik, Samsun 2012, s. 177-180.

16 Bk. Nedim Ipek, Imparatorluktan Cumhuriyete Göçler, Trabzon 2006; Nedim Ipek, Canik ve Göç, Samsun 2018.

17 Hasan Umur, Samsun'da Onbeş Sene, i̇stanbul 1947, s. 10-12, 37:; Rus işgali üzerine Trabzon'dan Samsun'a yönelik mülteci ve muhacir akımı için bk. Zamanın Izleri: Işgal, Göç ve Muhacirlik, Trabzon 2016. 
Birinci Dünya Savaşı esnasında cephe ve sahillerin güvenliğini sağlamak ve tedhiş harekâtını önleyebilmek adına Ermeni nüfusun ülkenin güneyine nakledilmesi kararlaştırılmıştı. İlgili talimata göre, ilk aşamada mahkumlar ve eylemlere katılanlar sevkedilecekti. Hasta ve sakat olanlar ile asker aileleri, memur, tüccar, amele ve ustalar, Katolik ve Protestan Ermeniler bu uygulamaya tabi tutulmayacaktı. Yetim çocuk ve dul kadınlar yetimhanelere veya bulundukları yerlerdeki köylere yerleştirileceklerdi. 20 yaşından küçük kızlar ile 10 yaş altı erkek çocuklar göç uygulaması dışında tutularak koruyucu statüsünde Türk ailelerin sorumluluğuna verilecektiler. Dost devletlerin tebaası Ermeniler de Canik sınırları içerisinde serbestçe dolaşabilecekler, başka bir vilayete gitmek isterlerse resmî makamları bilgilendireceklerdi. Yerel idarecilerin kefil olduğu ticaret erbabı Ermenilerin yer değişikliği sancak dâhili ile sınırlı kalacaktı. Ermeni mebus ve aileleri de yerlerinde kalacaklardı. Sevk ve iskân uygulamasına amele taburlarına kaydedilen ancak zapt edilemeyen 200 Ermeni'nin Sivas'a gönderilmesiyle başland1 (1915). ${ }^{[18]} 26$ Temmuz 1915 tarihli Canik Mutasarrıflı̆̆ının telgrafına göre Samsun şehrinden 3.711 Ermeni sevk ve iskana tabi tutulmuş, Ermeni mahallesi tamamen tahliye edilmişti. Romanya ve İran tabiyetindeki 5, 10 kişinin dışında şehirde Ermeni orjinli hiç kimse kalmamışt1. ${ }^{[19]}$ Ermeni sevkiyatı 15 Mart 1916'da tamamen durduruldu.

Birinci Dünya Savaşı esnasında şehirdeki Rumlar da göçürülme politikasına dâhil edildiler. Samsun uzun bir süre sadece Türklerin yaşadığı bir şehirdi. Tanzimat ile beraber şehre yönelik gayrimüslim göçü ve Kadıköy’ün belediye sınırlarına dâhil edilmesiyle şehirde bir Rum varlı̆̆ söz konusu olacaktır. Rumlar zamanla Kadıköy'ün yanı sıra yeni mahalleler de oluşturacaklardır. Rumların Türk mahallelerinde ikamet etmesi, kendilerine mahalle kurmaları Türk toplumunun olumsuz bir tepkisine sebebiyet vermez. Buna karşılık gayrimüslim köylerinden bir ikisine Balkan göçmeni yerleştirme teşebbüsü Rum köylüsünün tepkisini çeker. Söz konusu tepki güvenlik güçleri ile köylüleri karşı karşıya getirir. 8, 9 köy ahalisi kısmen silahlı ve kısmen ellerinde odun olduğu halde Çarşamba- Samsun şosesini kapatarak Ökse, Devgeriş, Çinik, Anderya, Çınarlı ve Çırakman’a muhacir yerleştirilmesine tepki göstermişler, jandarmaya direnmişler ve zorla Samsun’a girmeye çalışmışlardır. ${ }^{[20]}$ Öte yandan, Rusların Karadeniz’e inmesi, Samsun'un saldırıya açık bir şehir haline gelmesi halkta bir tedirginliğe sebebiyet verir. Aslında daha yıllar öncesinde Samsun kamuoyu dışarıdan limana yönelik bir saldırı halinde Rumların da karadan harekete geçmelerinden endişelenmekteydiler. Mutasarrıf heyecanı teskin edici nasihatlerde bulundu. Ama halkı teselli edemedi. Ancak herhangi bir çatışma olmadı. Samsun ve çevresindeki Rumlar Balkan Savaşı ile birlikte silâhaltına alınmaya başlanmıştı. Osmanlı ordusundaki Rum kökenli askerler

18 Nedim İpek, Canik ve Göç, Samsun 2018, s. 54-65; Hasan Babacan, "Birinci Dünya Harbinde Samsun ve Çevresinde Ermeni Tehciri Uygulamaları Üzerine Birkaç Belge”, Samsun Araştırmaları, 1, Samsun 2013, s. 285-305.

19 BOA, Dh. Şfr. 481/32.

20 BOA, Dh. Şfr. 428 / 86: Dah. Nezaretine Telgraf. 
Balkanlarda Yunan ordusuna karşı savaşmamak için çareyi firar etmekte buldular. Askeri ve adli takibattan korktukları için köylerine dönemeyen firari Rumlar Samsun ve çevresinde Pontus çetelerini oluşturmaya başladılar. Birinci Dünya Savaşı öncesinde başlatılan genel seferberlik ve hıristiyan yükümlülerin amele taburlarına yazılmaları da doğal olarak firari sayısını arttırır. Babıâli Rum çete faaliyetlerine karş1 1917'de Samsun'daki Rum nüfusu da sevk ve iskan uygulamasına dahil etti. ${ }^{[21]}$ Rumların sevkiyatı 1917 yılında da sürmüştür. Samsun'dan sevk edilen Rum nüfus Ocak 1917 tarihi itibarıyla 13.416 kişiydi. ${ }^{[22]}$ Bunların Ankara, Amasya, Çorum'daki yerleşmelere dağıtıldığı anlaşılmaktadır.

İleriki tarihlerde sevk ve nakil işlemine tabi tutulanların ocaklarına dönmelerine izin verildi. Ahmet İzzet Paşa sevk ve iskân uygulamasını hükümet programına koydu. Hükümet beyannamesinde sevk ve iskan uygulamasına dahil edilen Osmanlı vatandaşlarının ocaklarına dönmesine karar verildiği, hatta icraata başlandığı ve mal varlıklarının kendilerine iade edileceği bildirilmişti. Aralık 1918’e kadar Samsun’a 456 Rum ve 271 Ermeni dönmüştü. Geri dönüş özellikle mal varlıklarının iadesinde yeni sorunların ortaya çıkmasına sebebiyet vermiştir. Geri dönenlerin sayısı ile ilgili elimizde herhangi bir veri bulunmamaktadır. Şehirdeki Rum varlığg 1920 itibarıyla Kadıköy'de 1.540, Rum mahallesinde ise 3.592 kişiydi. ${ }^{[23]}$

9 Mart 1919'da İngiliz İşgal Kumandanlığı asayiş gerekçesiyle 200 kişilik bir birliği Samsun'a çıkardı. Zamanla bunların sayısı 450'ye yükseldi. Bunların bir kısmı Merzifon’a gönderildi. 7 Temmuz 1919'da Mustafa Kemal Paşa’yı baskıda tutmak için Hint, Avustralya, Yeni Zellandalı 1200 asker de Samsun'a çıkarıld ${ }^{[24]}$ ve bir kısmı İlyasköy kışlalarına yerleştirildi. Şehirdeki Rumlar işgal kuvvetlerini sevinç gösterileri ile karşılamışlardı İngiliz askerleri sokaklarda dolaşmakta ve ahlak kurallarına uymayan kepazeliklerde bulunmaktaydılar. Rumlar Kadıköy'de zaman zaman yaylım ateşi açıyorlardı. Metropolithane önünde Rum mekteplerinde Yunan bayrakları dalgalanıyordu. Özellikle geceleri Rumlara ait evlerden Yunan marşı, Venizelos şarkıları yükseliyordu. ${ }^{[25]}$

Rumların sevincine karşı Türklerde korku, telaş ve heyecan vardı. Şehirdeki Türklerin mühim bir kısmı meçhul bir karanlığa gidildiğini fark ediyor ama kur-

21 Nedim İpek, Canik ve Göç, Samsun 2018, s. 65-82.

22 Dh. Şfr. Nu. 548 / 1: 12.1. 1333.

23 Bünyamin Kocaoğlu, Milli Mücadele Yıllarında Samsun 15. Fırkanın Samsun'daki Faaliyetleri (1919-1921), Samsun 2008, s. 92-93.

24 Mehmet Okur, “Milli Mücadele Döneminde İngilizlerin Samsun’daki Faaliyetleri ve Bölgeyi Tahliyeleri”, 19 Mayıs ve Milli Mücadelede Samsun Sempozyumu, Samsun 2000, s. 301-306.

25 Cephe ve Esaret Hatıraları, Yayına Hazırlayan. Yusuf Gedikli, İstanbul 2011, s. 46-47; Erdal Aydoğan, "Mustafa Kemal Paşa’nın Samsun Bölgesinde Jandarma Birlikleri Oluşturma Faaliyetleri", 19 Mayıs ve Milli Mücadelede Samsun Sempozyumu, Samsun 2000, s. 18 
tuluş çaresini arama kudretini gösteremiyordu. Durumun vahametini idrak eden vatandaşlar endişeli bir şekilde kurtuluş çarelerini arar oldular. İşte bunlar ileri de Samsun'da Cemiyet-i Hayriye-i İslamiye, İhtiyat ve Zabitan Cemiyeti, Karadeniz Türkleri Müdafaa-i Hukuk Cemiyeti’ni kurarak Milli Mücadele’ye katkı vereceklerdir.

Birinci Dünya Savaşı esnasında emperyalist devletler Osmanlı Devleti'nin elinde kalan Anadolu topraklarında Mora, Tuna ve Makedonya'da uygulanan yapay ulus devlet kurma projelerini sahneye koymuştu. Planlamaya göre Doğu Anadolu'da Ermenistan ve Kürdistan, Batı Anadolu'da İyonya ve Doğu Karadeniz'de Pontus devleti kurmak. Yapay ulus devlet kurma yöntemini kısaca hatırlamak gerekirse kurulacak devletin adeta yaradılışta kurulduğu izlenimi vermek amacıyla ilkçağlarda kullanılan bir siyasi isim seçilir. Bu isim bir coğrafyaya yakıştırılır ve zamanla sorun haline dönüştürülür: Makedonya, Makedonya sorunu; Pontus, Pontus sorunu şeklinde. Sonra devletin nüvesini oluşturacak gayrimüslim unsur belirlenir. Bu toplumun söz konusu sahadaki nüfusunu artırıcı tedbirler alınır. Ardından bölgede yaşayan farklı etnik unsurlar kurulan çeteler vasıtasıyla birbirine karşı ötekileştirilir. Akabinde meydana gelen toplumsal çatışmayı önleme iddiası ile bölgeye askeri veya diplomatik yöntemlerle müdahale edilir. Bundan sonra devleti kurması istenen nüfusu çoğunluk haline getirebilmek için soykırım ve göçürme yöntemleri ile istenmeyen nüfus yok edilmeye çalışılır. ${ }^{[26]}$

Söz konusu yöntem genel savaşla Doğu Karadeniz bölgesinde de sahneye kondu. Sinop- Batum arasında Karadeniz sahil hattında Rumlar vasitasiyla Pontus isimli bir devletin kurulması projesi geliştirildi. Bu projenin alt yapısını hazırlamak amacıyla Samsun Rum Muhacirin Cemiyeti, Pontus İdman Klübü, İrfanperver Klübü, Müdafaa-i Meşrute Cemiyeti, Mukaddes Rum Anadolu Cemiyeti, Rum Teceddüt ve Ihya Cemiyeti kuruldu ve faaliyete geçirildi. ${ }^{[27]}$ İngilizler Samsun'a çıktıklarında Rum çetelerine 10 bin silah dağıttılar. Sonra Pontus bölgesinde sayıları pek az olan Rumları çoğaltmak için Rusyada ikamet eden ve Bolşevik rejiminden hoşlanmayan Rumları Samsun çevresine nakletmeye ve yerleştirmeye çalıştılar. Rumlar şehirde silahla dolaşıyor, Saathane'de düzenledikleri at yarışlarında atları hükümet konağının önüne kadar sürmekten çekinmiyorlardı. Böylece Osmanlı otoritesini tanımadıklarını gösteriyorlardı. Çeteler Müslim nüfusu azaltmak amacıyla Türk yerleşmelerine saldırmaya başladı. Gayrimüslim unsurları cüretlendiren İngiliz işgal kuvvetleri ile şehrin açıklarında demirli duran Amerikan savaş gemisiydi. ABD, Karadeniz ve

26 Cephe ve Esaret Hatıraları, Yayına Hazırlayan. Yusuf Gedikli, İstanbul 2011, s. 46-47; Erdal Aydoğan, "Mustafa Kemal Paşa’nın Samsun Bölgesinde Jandarma Birlikleri Oluşturma Faaliyetleri", 19 Mayıs ve Milli Mücadelede Samsun Sempozyumu, Samsun 2000, s. 18

27 Pontus Meselesi, Yayına Hazırlayan. Yılmaz Kurt, Ankara 1995, s. 249. 
havalisindeki ekonomik menfaatlerini korumak adına Amerikan donanmasına ait gemileri Karadeniz'e sevk etmişti. Bu gemilerin sayısı 12 civarındaydı. Bunlardan birisi de yukarıda belirtildiği üzere Samsun limanı açıklarında demirli tutuluyordu. Amaç şehirdeki Hristiyanları himaye etmek, Pontusçulara destek vermek, Amerikan şirketlerinin ve temsilcilerinin güvenliğinin sağlamaktı. ${ }^{[28]} 1919$ yılının başından itibaren Amerikalı iş adamları Amerikan donanmasına ait savaş gemilerinin desteğinde Samsun’a gelmeye başladılar. Şehirdeki İngiliz kontrol subayları Pontuslculuğa yönelik her türlü desteği vermekten imtina etmediler.

İşgalci kuvvetler desteğindeki Rum çeteleri bölgenin nüfus yapısını değiştirmek ve Türkleri göçürmek amacıyla tedhiş harekatlarında bulundu. 1915- 1920 yılları arasında yedisi şehirde olmak üzere kaza dahilinde 51 Türk katledildi. ${ }^{[29]}$ Çevre kazalar dahilindeki yerleşmelerde durum şehirle mukayese edilmeyecek ölçüde daha vahim bir durumdaydı. Demografik mühendislik için müracaat edilen bir diğer yöntem bölgeye Rum kolonist getirmekti. Rum nüfusu arttırmak için Rusya, Kafkasya, Doğu Anadolu ve Orta Anadolu’daki Rumlar Doğu Karadeniz'e sevk ve nakledilmeye çalışıldı. Osmanlı idaresi İngiltere’nin kontrolünde bir Pontus devleti kurulması korkusuyla Rum göçmenlerin ocaklarına dönüşünü durdurdu. Öte yandan Rusya, Kafkasya ve Amerika'dan Rum göçünü kesin olarak önlemeye çalıştı. Ardından ecnebi tabiiyetine mensup Rumların göçünü kesin olarak yasakladı. Belirtmek gerekirse 18 Aralık 1919'da İngiltere ve Yunanistan idarelerinin desteği ile Batum'da Sarraf Yuvanidis Efendi riyasetinde Pontus Rum Hükümeti kurulacaktır. ${ }^{[30]}$

İşte böyle bir ortamda Mustafa Kemal Paşa Karakaş Mustafa isimli kişinin motoruyla tütün iskelesine çıktı. İskeleye çıkan müfettişlik heyeti 55 kişiden oluşmaktaydı. Mustafa Kemal Paşa ve karargâhı mensupları 15. Tümenden Kurmay Binbaşı Mahmut Ekrem Bey'in mihmandarlığında bir manga asker tarafından karşılandı. Mutasarrıf Edhem Bey, tümen kumandanı, belediye başkanı ve şehrin diğer ileri gelenleri karşılamada bulunmadılar. Şehir adına Boşnakzade Süleyman heyete hoş geldiniz dedi. İskeledeki kısa bir karşılama töreni icra edildikten sonra Mustafa Kemal ve beraberindekiler 19 Mayıs sabahı saat 8, 9 sularında yürüyerek Mıntıka Palas’a geldiler. Müfettişliğin forsu otelin balkonuna asıldı. Mustafa Kemal'in Samsun’a çıktığı gün 50 kişilik bir Rum çetesi Kurupelit karakolunu basmışt1. ${ }^{[31]}$ Netice itibarıyla Mustafa Kemal Paşa ve refakatindekiler böyle bir ortamda Milli Mücadele’yi planlayıp işe başlayacaklardır.

28 Hikmet Öksüz, "Amerikalıların Canik Sancağı ile İlgili Hazırlamış Oldukları Bir Rapor (1917-1919)", illkadımdan Cumhuriyete Milli Mücadele, İstanbul 2008, s. 99-108.

29 Pontus Meselesi, Yayına Hazırlayan. Yılmaz Kurt, Ankara 1995, s. 249.

30 Selçuk Ural, "Mütareke Döneminde Pontus Hareketinin Doğuşuna Yönelik Faaliyetler", Başlangıçtan Günümüze Pontus Sorunu, Ankara 2007, s. 225-247.

31 Bölgenin asayişi ile ilgili Mustafa Kemal Paşa’nın kaleme aldığı rapor içib bk. Atatürk lle Illgili Arşiv Belgeleri (1911-1921) Tarihleri Arasına Ait 106 Belge, Ankara 1982, Bölgenin asayişi ile ilgili Mustafa Kemal Paşa’nın kaleme aldığı rapor için bk. s. 30-32. 


\section{KAYNAKLAR}

Anabasisten Atatürk’e Seyahatnamelerde Trabzon, Yay. Haz. Veysel Usta, Trabzon 1999.

Atatürk Ile Illgili Arşiv Belgeleri (1911- 1921) Tarihleri Arasına Ait 106 Belge, Ankara 1982.

AYdoĞAN, Erdal, "Mustafa Kemal Paşa’nın Samsun Bölgesinde Jandarma Birlikleri Oluşturma Faaliyetleri”, 19 Mayıs ve Milli Mücadelede Samsun Sempozyumu, Samsun 2000, ss. 17- 23.

BABACAN, Hasan, "Birinci Dünya Harbinde Samsun ve Çevresinde Ermeni Tehciri Uygulamaları Üzerine Birkaç Belge", Samsun Araştırmaları, 1, Samsun 2013, ss. 285- 305.

Cephe ve Esaret Hatıraları, Yay. Haz. Yusuf Gedikli, İstanbul 2011.

EKEN, Halit, “Mutasarrıf Hamid Bey’in Özel Notlarında 1919 Yılında Canik Sancağındaki Siyasi Olmayan Asayiş Sorunları ve Çözüm Arayışları", 19 Mayıs ve Milli Mücadelede Samsun Sempozyumu, Samsun 2000, ss. 117135.

FRUNZE, Mihail Vasilyeviç, Frunze’nin Türkiye Anıları, Çeviren. Ahmet Ekeş, İstanbul 1996.

IPEK, Nedim, Rıza Karagöz, Cihat Uslucan, Canik Sancağı Samsun Kazasının Nüfus Yapısı (1834- 1845), Samsun 2016.

IPEK, Nedim, Canik ve Göç (1800-1923), Samsun 2018.

IPEK, Nedim, Imparatorluktan Cumhuriyete Göçler, Trabzon 2006.

IPEK, Nedim, "Kuruluşundan Cumhuriyete Canik Sancak Merkezi Samsun Şehri”, Ilkçağdan Cumhuriyete Canik, Samsun 2012, ss. 164- 226.

IPEK, Nedim, "Samsun- Sivas Demiryolu”, Ciepo Osmanlı Öncesi ve Osmanlı Araştırmaları Uluslararası Komitesi 17. Sempozyumu Bildiriler, Trabzon 2006, ss. 863- 874.

IPEK, Nedim, "Osmanlı Coğrafyasında Yapay Ulus Devlet Kurma Projeleri”, Başlangıçtan Günümüze Pontus Sorunu, Ankara 2007, ss. 11- 28.

KARAGÖZ, Rıza, “Canik’in İdari Yapısı ve İdarecileri”, Ilkçağdan Cumhuriyete Canik, Samsun 2012, ss. 119- 162.

KARAGÖZ, Riza, Canikli Ali Paşa, Ankara 2003.

KARAGÖZ, Riza, Karadeniz'de Bir Hanedan Kurucusu Haznedarzade Süleyman Paşa, Samsun 2010.

KOCAOĞLU, Bünyamin, Milli Mücadele Yıllarında Samsun 15. Fırkanın Samsun'daki Faaliyetleri (1919- 1921), Samsun 2008.

KÖSE, Osman, “Rusların Samsun’u Bombardımanı (1915)”, Geçmişten Geleceğe Samsun, 2, Samsun 2007, ss. 95- 112. Pontus Meselesi, Yayına Hazırlayan. Yılmaz Kurt, Ankara 1995.

SERBESTOĞLU, Ibrahim, Tanzimat, Teftiş ve Canik Sancağında Modernleşme, Ankara 2019.

OKUR, Mehmet, "Milli Mücadele Döneminde İngilizlerin Samsun'daki Faaliyetleri ve Bölgeyi Tahliyeleri”, 19 Mayıs ve Milli Mücadelede Samsun Sempozyumu, Samsun 2000, ss. 299- 313.

ÖKSÜZ, Hikmet, "Amerikalıların Canik Sancağı ile Illgili Hazırlamış Oldukları Bir Rapor (1917-1919)", Ilkadımdan Cumhuriyete Milli Mücadele, İstanbul 2008, ss. 99- 108.

ÖZ, Mehmet, XV-XVI. Yüzyıllarda Canik Sancağı, Ankara 1999.

TELLIOĞLU, Ibrahim, Ilkçağdan Osmanlılara Samsun, Samsun 2012.

TELLIOĞLU, Ibrahim, "Osmanlı Hakimiyetine Kadar Canik”, Ilkçağdan Cumhuriyete Canik, Samsun 2012, ss. 23- 67. UMUR, Hasan Umur, Samsun'da Onbeş Sene, İstanbul 1947.

URAL, Selçuk, "Mütareke Döneminde Pontus Hareketinin Doğuşuna Yönelik Faaliyetler", Başlangıçtan Günümüze Pontus Sorunu, Ankara 2007, ss. 225- 247.

Zamanın Izleri: Işgal, Göç ve Muhacirlik, KTü Yayını, Trabzon 2016. 


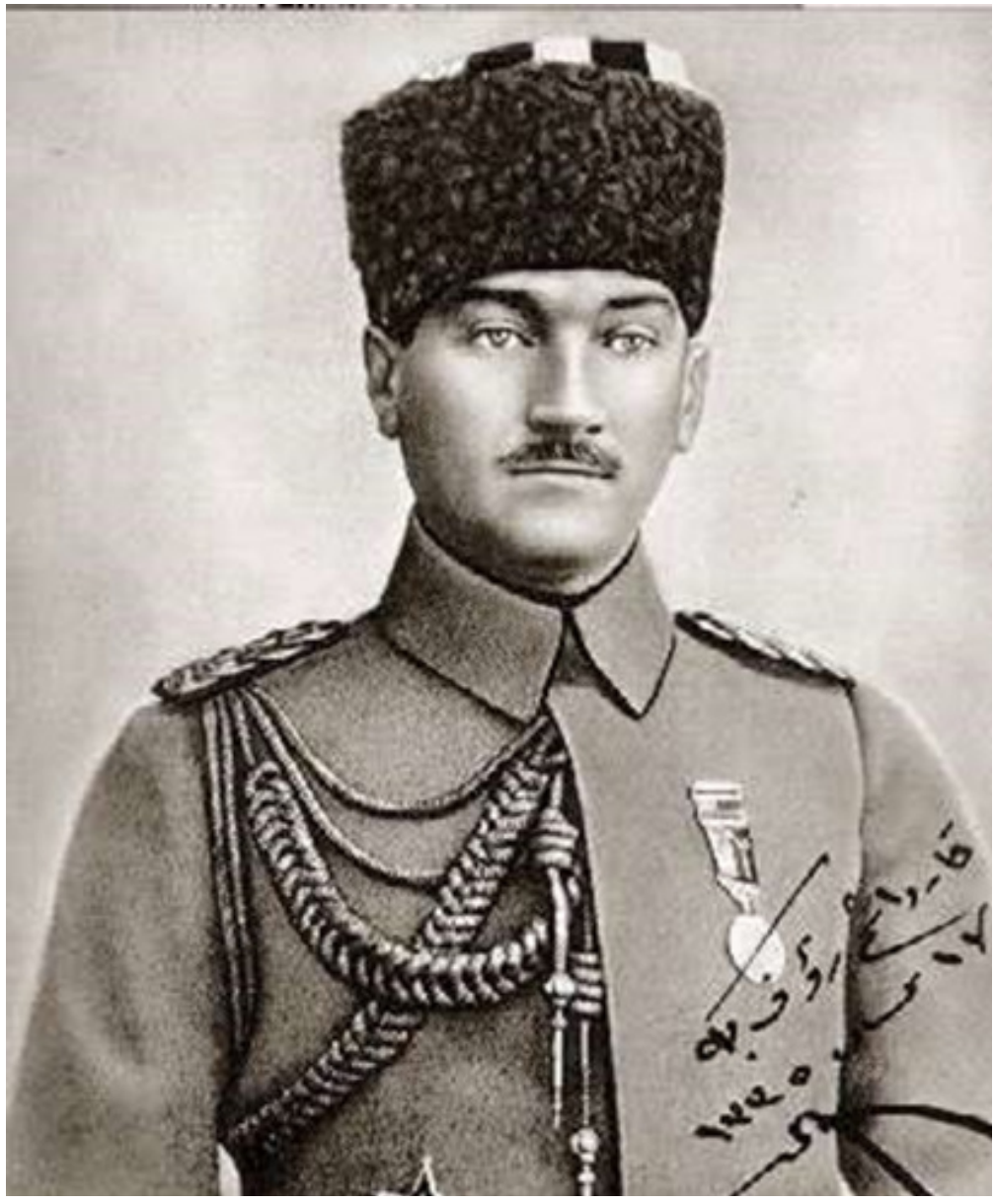

"Kardeşim Rauf Bey’e: 17 Nisan 1335." 

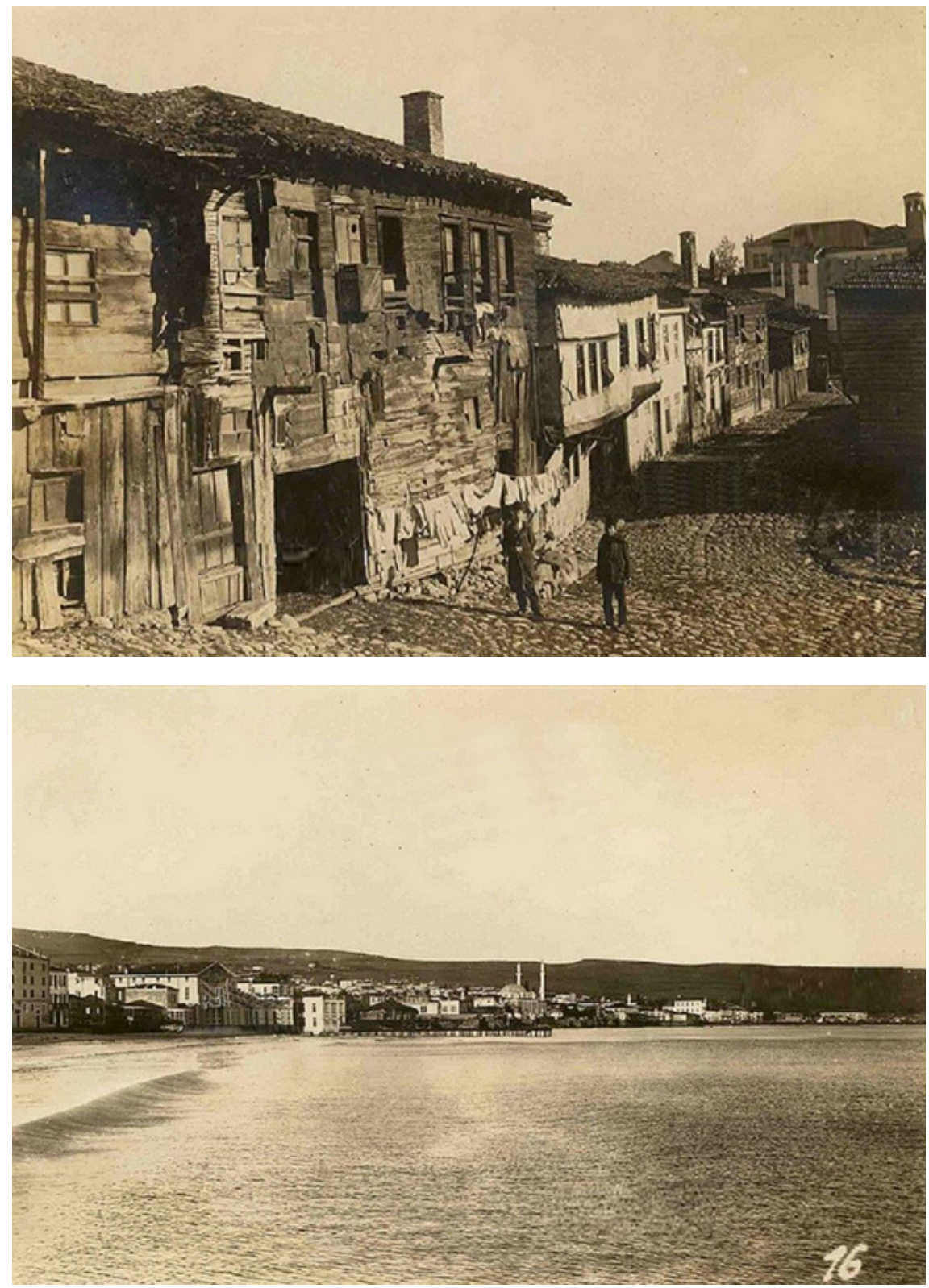

Samsun 1918: İpek, Canik ve Gö̧, s. 133, 259.

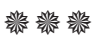

